\title{
Acute and long-term proteome changes induced by oxidative stress in the developing brain
}

\author{
AM Kaindl ${ }^{*, 1,2,3}$, M Sifringer $^{3}$, C Zabel $^{2}$, G Nebrich $^{2}$, MA Wacker $^{2}$, \\ U Felderhoff-Mueser ${ }^{4}$, S Endesfelder ${ }^{3}, M^{2}$ von der Hagen ${ }^{3}$, \\ V Stefovska ${ }^{3}, \mathrm{~J} \mathrm{Klose}^{2}$ and C Ikonomidou ${ }^{3}$ \\ 1 Department of Pediatric Neurology, Charité, University Medical School, \\ Campus Virchow-Klinikum, Augustenburger Platz 1, 13353 Berlin, Germany \\ 2 Institute of Human Genetics, Charité, University Medical School, Campus \\ Virchow-Klinikum, Augustenburger Platz 1, 13353 Berlin, Germany \\ 3 Department of Pediatric Neurology, University Children's Hospital, Technical \\ University Dresden, Fetscher Str. 74, 01307 Dresden, Germany \\ ${ }^{4}$ Department of Neonatology, Charité, University Medical School, Campus \\ Virchow-Klinikum, Augustenburger Platz 1, 13353 Berlin, Germany \\ * Corresponding author: AM Kaindl, Department of Pediatric Neurology, Charité \\ University Medical School, Augustenburger Platz 1, 13353 Berlin, Germany. \\ Tel: + 4930450 566112; Fax: + 4930450 566920; \\ E-mail: angela.kaindl@charite.de
}

Received 15.3.05; revised 31.8.05; accepted 22.9.05; published online 28.10.05 Edited by L Greene

\begin{abstract}
The developing mammalian brain experiences a period of rapid growth during which various otherwise innocuous environmental factors cause widespread apoptotic neuronal death. To gain insight into developmental events influenced by a premature exposure to high oxygen levels and identify proteins engaged in neurodegenerative and reparative processes, we analyzed mouse brain proteome changes at P7, P14 and P35 caused by an exposure to hyperoxia at P6. Changes detected in the brain proteome suggested that hyperoxia leads to oxidative stress and apoptotic neuronal death. These changes were consistent with results of histological and biochemical evaluation of the brains, which revealed widespread apoptotic neuronal death and increased levels of protein carbonyls. Furthermore, we detected changes in proteins involved in synaptic function, cell proliferation and formation of neuronal connections, suggesting interference of oxidative stress with these developmental events. These effects are age-dependent, as they did not occur in mice subjected to hyperoxia in adolescence.

Cell Death and Differentiation (2006) 13, 1097-1109.

doi:10.1038/sj.cdd.4401796; published online 28 October 2005
\end{abstract}

Keywords: hyperoxia; oxidative stress; neurodegeneration; brain proteome; developing brain

Abbreviations: 14-3-3, tyrosine 3-monooxygenase/tryptophan 5-monooxygenase activation protein; ANT1, adenine nucleotide translocatase 1; ANX5, annexin A5; AP1GBP1, AP1 gamma subunit binding protein 1; ATP6V1, ATPase, $\mathrm{H}+$ transporting, $\mathrm{V} 1$ subunit D; BAT1, nuclear RNA helicase Bat1; CDC2, cell division control protein 2 homolog; CFL, cofilin; CLAPM1, clathrinassociated adaptor complex AP-2 miu2 chain; CRMP, collapsin response mediator protein; 2-DE, two-dimensional electrophoresis; DCX, doublecortin; DNP, 2,4-dinitrophenylhydrazine; EEF1D, elongation factor 1-delta; GAP43, neuromodulin; GSTM1, glutathione S-transferase, mu 1; GPD2, glycerol-3phosphate dehydrogenase 2; HNRNPQ, heterogeneous nuclear ribonucleoprotein $\mathrm{Q}$; IEF, isoelectric focussing; I2PP2A, protein phosphatase 2A inhibitor 2I; MAP/SimMAP, microtubule-associated protein/similar to MAP; MLC, myosin regulatory light chain; MPP6, MAGUK p55 subfamily member 6; MS, mass spectrometry; NDR2, N-myc downstream regulated 2; NDUFA9/S1, $\mathrm{NADH}$-ubiquinone oxidoreductase $39 \mathrm{kDa}$ subunit/Fe-S protein 1; NDUVF1, NADH-ubiquinone flavoprotein 1; PACSIN1, protein kinase $C$ and casein kinase substrate in neurons; PDCD5, programmed cell death 5; PEA15, phosphoprotein enriched in astrocytes 15; PHB, prohibitin; PIN1, peptidyl-prolyl cis-trans isomerase NIMA-interacting 1; PRDX2, peroxiredoxin 2; PSMA1/ 3, proteasome subunit alpha type 1/3; PYGB, brain glycogen phosphorylase; Rab GDI 1/Rho GDI 1, Rab/Rho GDP dissociation inhibitor 1; RBM8A, RNA binding motif protein 8A; SF1, splicing factor 1; SYN, synapsin; STXBP2, syntaxin binding protein 2; TUBA6, tubulin alpha-6 chain; TPPP, tubulin polymerization-promoting protein; UBQLN2, ubiquilin 2; UQCRBP, ubiquinol-cytochrome $c$ reductase binding protein; VDAC, voltage-dependent anion channel

\section{Introduction}

While the mortality of children with extremely low birth weight and gestational age has decreased markedly due to advances in perinatal care, long-term neurologic morbidity continues to impose a major personal burden for affected individuals and their families and constitutes a considerable socioeconomic problem. ${ }^{1,2}$ Brain imaging studies of survivors of premature birth have demonstrated that motor deficits correlate with white matter damage whereas cognitive deficits correlate with decreased volume of gray matter structures. ${ }^{3,4}$ These findings suggest that neuronal loss, occurring in the brains of premature infants postnatally, is partly responsible for their neurologic morbidity. However, in many cases, there is neither an obvious clinical explanation nor a corollary on conventional imaging studies for the neuropsychologic morbidity. Recent work has emphasized the role of intrauterine and neonatal infections, ${ }^{5}$ pharmacologic agents ${ }^{6,7}$ and oxygen $^{8-10}$ in triggering neuronal death in the developing mammalian brain.

Depending on the time of impact, lesions of the immature central nervous system (CNS) have the potential to influence developmental events at their natural sequence and redirect subsequent development. ${ }^{11}$ The CNS of preterm infants is particularly sensitive to free radical-mediated oxidative stress. $^{12}$ These newborns not only exhibit developmental immaturity of their free radical defences, but they are also inevitably exposed to relative hyperoxia compared to intrauterine hypoxic conditions and are more likely to encounter 
further situations of increased oxidative stress, such as oxygen supplementation, to aid impaired respiration, or systemic infections. We recently demonstrated that increased oxygen tension is a powerful trigger for widespread apoptotic cell death in the developing rodent brain. ${ }^{9}$ This hyperoxiainduced apoptosis is associated with oxidative stress, upregulation of inflammatory cytokines, decreased expression of neurotrophins and decreased activation of neurotrophin-regulated pathways. ${ }^{9,10}$ The timing of greatest vulnerability coincides with the peak of the brain growth spurt, which starts at about midpregnancy in humans and extends well into the third postnatal year. In mice and rats, this developmental period occurs within the first three postnatal weeks; ${ }^{13}$ cross-species extrapolation with regard to the timing of the main brain growth spurt period thereby renders 6-dayold mice a model for preterm human infants. Preceded by a period of maximal neuronal proliferation, processes at risk during this phase include glial proliferation and myelination, the explosive increase of dendritic complexity, the establishment of synaptic connections as well as reorganization events. $^{13,14}$

The aim of the present study was to explore changes in brain proteome following hyperoxia-induced oxidative stress, gain insight into developmental events that are disrupted by hyperoxia and identify novel proteins potentially involved in reparative processes. Our results of brain proteome analysis point towards a number of phenomena whose dysregulation due to oxidative stress can potentially influence normal development and give rise to neurologic and neurocognitive deficits.

\section{Results}

\section{Brain proteome changes of hyperoxia-treated infant mice}

To identify proteome changes caused by hyperoxia in infant mouse brains (P6), we separated total protein extracts of left brain halves of hyperoxia-treated and control mice by twodimensional electrophoresis (2-DE) immediately, 1 and 4 weeks after treatment. An analysis of hyperoxia-induced brain protein changes in older, juvenile mice (P35) served as a means to determine the specificity of observed proteome changes for the immature brain. Proteins were resolved according to their isoelectric point ( $\mathrm{pl}$ ) in the first and their molecular weight (Mw) in the second dimension. After silver staining of the 2-DE gels, we detected approximately 8000 discrete spots per sample (Figure 1). On a 2-DE gel, one protein may be represented by one spot or constitute a pattern of multiple spots (isospots) caused by co- and/or posttranslational modifications of the primary protein product or by protein processing. Such modifications may result in alterations of $\mathrm{pl}$, molecular mass and/or conformation of a protein and consequently cause a shift in the position of a spot on a 2DE gel and thus a change of spot intensity, that is, decrease in the relative concentration of an unmodified protein. Protein isospots within discrete spot complexes, arrangements of several isospots in a dense cluster in 2-DE patterns that showed the same change upon hyperoxia, are referred to by one spot number. Spots can also be considered in terms of spot families, that is, the total number of isospots within a 2DE protein pattern that were created from one primary protein. Since members of a spot family may be distributed over an entire 2-DE protein pattern, a detection of all members would require the analysis and identification of all protein spots visualized on a 2-DE gel by mass spectrometry (MS). Since we identified only those proteins by MS that were altered upon hyperoxia, we cannot exclude that other unaltered protein spots exist for a specific spot family.

Through a comparison of brain proteomes in 2-DE protein patterns, we detected reproducible qualitative differences in 67,12 and 26 protein spots of mice treated with hyperoxia in infancy as compared to untreated littermates at P7, P14 and P35, respectively (Figures 1 and 2). Changes in spot intensities usually varied in the range of $20-100 \%$ increase or decrease. MALDI-MS and/or ESI-MS enabled the identification of 48, 12 and 23 discrete proteins (protein families) at P7, P14 and P35, respectively (Table 1). These brain protein isoforms were not differentially regulated in mice subjected to toxic oxygen levels in adolescence (P28-34). Proteins altered in young mice have been associated with oxidative stress, apoptosis, cell maintenance and growth, synaptic function, vesicular transport and axonal growth and guidance.

\section{Changes in proteins associated with oxidative stress, apoptosis and growth}

We identified acute and long-term changes in six brain proteins that can be linked to hyperoxia-induced increased production of reactive oxygen species (ROS) and increased rates of apoptosis in the developing rodent brain (Figure 2a). The observed acute depletion of free radical defences such as peroxiredoxin 2 may decrease the activity of redox-sensitive proteins. A dysregulation of tyrosine 3-monooxygenase/ tryptophan 5-monooxygenase activation protein (14-3-3) polypeptides was detected in response to hyperoxia. A shift

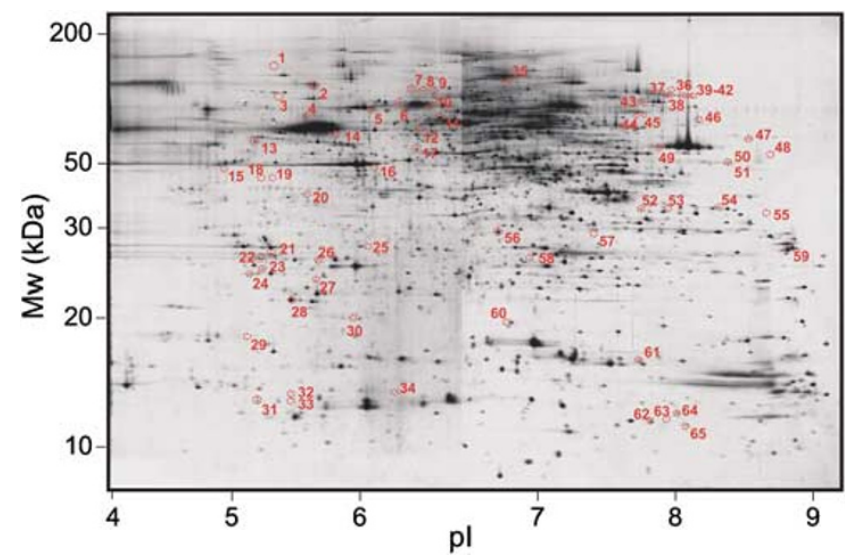

Figure 1 Overview of brain proteins altered acutely in hyperoxia-treated infant mice. The representative 2-DE brain protein pattern (left hemisphere) shown with a resolving power of about 8000 discrete protein spots stems from a 7-day-old male mouse exposed to hyperoxia at P6. By 2-DE, brain proteins are resolved according to their isoelectric point (pl) in the first and their $\mathrm{Mw}$ in the second dimension. Numbers mark 67 protein spots that were reproducibly altered in response to hyperoxia 
a Oxidative Stress and Apoptosis

H

\begin{tabular}{|c|c|c|}
\hline $14-3-3$ B & $14-3-3 \zeta$ & 12PP2A \\
\hline-.22 & $\theta_{-023}$ & $-027 \hat{4}$ \\
\hline
\end{tabular}

C
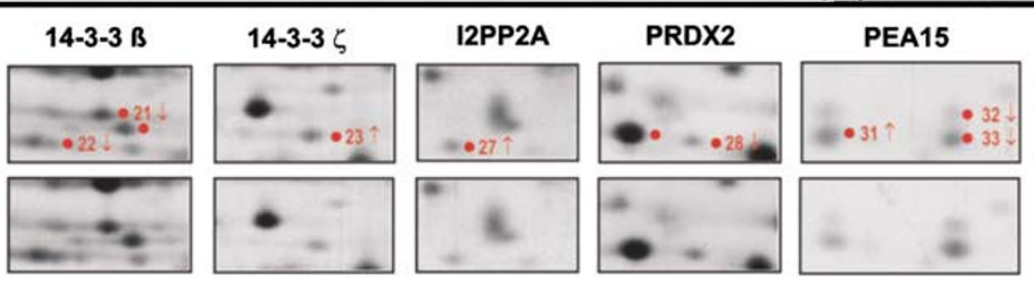

PDCD5

b

Growth and Energy Metabolism

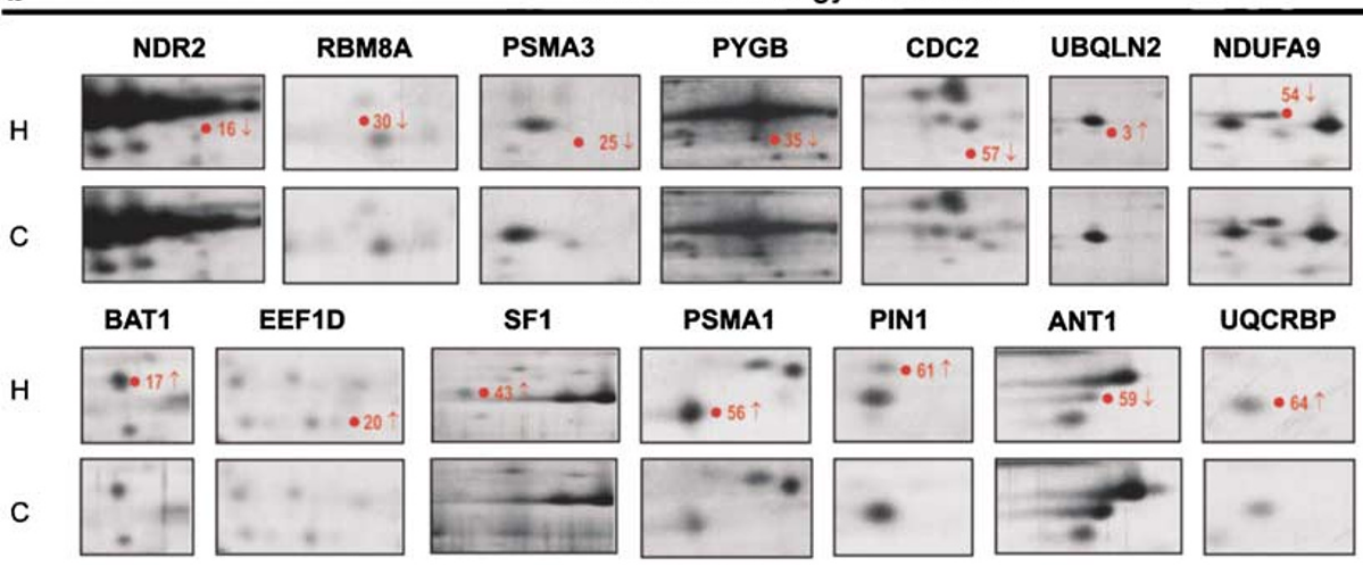

C

Synapse Function

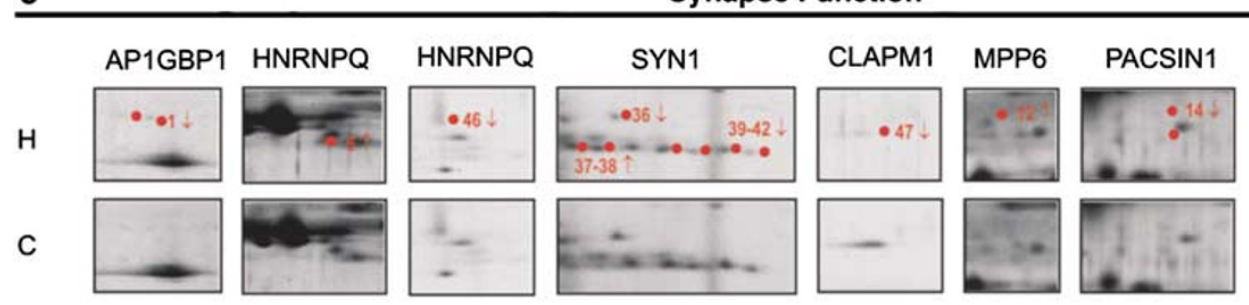

d

Axon Growth and Guidance

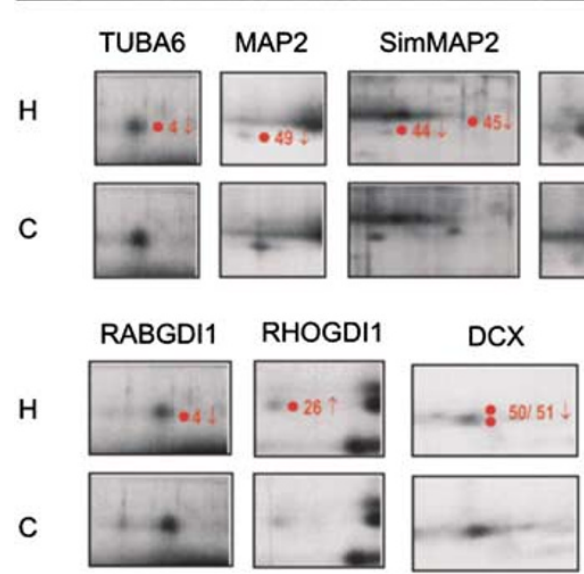

Figure 2 Proteins altered acutely in response to hyperoxia. The comparison of brain proteomes of hyperoxia-treated mice and controls at P7 revealed reproducible changes in the intensity of 48 proteins ( 67 protein spots) in response to hyperoxia at P6. Some proteins such as CRMP2 are represented by several isospots (isoforms) on 2-DE gels. Most of these proteins are associated with (a) oxidative stress and/or apoptosis, (b) growth and energy metabolism, (c) synapse function/vesicular transport and (d) axon growth and guidance. Altered spots are marked by red dots on their right side and identified by numbers (see Table 1); the upward and downward arrows mark an increase or decrease, respectively, of a spot intensity in hyperoxia-treated mice as compared to their untreated littermates. For an explanation of abbreviations, please refer to Table 1 


\begin{tabular}{|c|c|c|c|c|c|}
\hline \multirow[b]{2}{*}{$\begin{array}{l}\text { Accession } \\
\text { number }\end{array}$} & \multirow[b]{2}{*}{$\begin{array}{c}\text { Spot } \\
\text { number }\end{array}$} & \multirow[b]{2}{*}{ Protein } & \multicolumn{3}{|c|}{ Quantitative changes $(\%)^{\star *}$} \\
\hline & & & $\begin{array}{l}\text { P7 } \\
\text { acute }\end{array}$ & $\begin{array}{c}\text { P14 } \\
\text { after } 1 \text { week }\end{array}$ & $\begin{array}{c}\text { P35 } \\
\text { after } 4 \text { weeks }\end{array}$ \\
\hline \multirow{2}{*}{\multicolumn{6}{|c|}{ A. Proteins involved in oxidative stress and apoptosis }} \\
\hline Q9CQV8 & & & & & $\nabla 49(6)$ \\
\hline Q9CQV8 & 22 & $14-3-3$ protein, beta polypeptide $(14-3-3 \beta)$ & $\nabla 24(5)$ & & \\
\hline P63101 & 23 & $14-3-3$ protein, zeta polypeptide $(14-3-3 \zeta)$ & $\Delta 44(4)$ & & \\
\hline P62259 & 75 & $14-3-3$ protein, epsilon polypeptide $(14-3-3 \varepsilon)$ & & & $\nabla 69(6)$ \\
\hline P61982 & 80 & 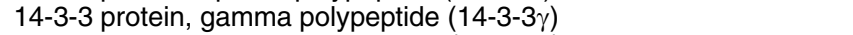 & & & $\nabla 41(4)$ \\
\hline Q9EQU5 & 27 & Protein phosphatase $2 \mathrm{~A}$ inhibitor 2 I (I2PP2A) & $\Delta 67(5)$ & & \\
\hline Q61171 & 28 & Peroxiredoxin 2 (PRDX2) & $\bar{\nabla} 12(4)$ & & \\
\hline Q61910 & 31 & Phosphoprotein enriched in astrocytes 15 (PEA15) & $\Delta 84(5)$ & & \\
\hline Q61910 & 32 & Phosphoprotein enriched in astrocytes 15 (PEA15) & $\nabla 85(5)$ & & \\
\hline Q61910 & 33 & Phosphoprotein enriched in astrocytes 15 (PEA15) & $\nabla 85(5)$ & & \\
\hline P56812 & 34 & Programmed cell death 5 (PDCD5) & $\nabla 50(6)$ & & \\
\hline P48036 & 66 & Annexin A5 (ANX5) & & $\nabla 35(5)$ & \\
\hline \multicolumn{6}{|c|}{ B. Proteins involved in growth and energy metabolism } \\
\hline Q8C661 & 16 & N-myc downstream regulated 2 (NDR2) & $\nabla 54(5)$ & $\nabla 59(4)$ & \\
\hline Q9Z1N5 & 17 & Nuclear RNA helicase Bat1 (BAṪ1) & $\Delta 12$ (4) & $\nabla 32(4)$ & \\
\hline Q9CWZ3 & 30 & RNA binding motif protein $8 A$ (RBM8A) & $\nabla 70(4)$ & & \\
\hline Q9R1P4 & 56 & Proteasome subunit alpha type 1 (PSMA1) & $\Delta 17(4)$ & & \\
\hline 070435 & 25 & Proteasome subunit alpha type 3 (PSMA3) & $\nabla 69$ (5) & & \\
\hline Q8Cl94 & 35 & Brain glycogen phosphorylase (PYGB) & $\nabla 53(4)$ & & \\
\hline P11440 & 57 & Cell division control protein 2 homolog (CDC2) & $\nabla 43(4)$ & & \\
\hline Q9QZM0 & 3 & Ubiquilin 2 (UBQLN2) & $\Delta 100(6)$ & & \\
\hline P57776 & 20 & Elongation factor 1-delta (EEF1D) & A 217 (4) & & \\
\hline Q64213 & 43 & Splicing factor 1 (SF1) & $\Delta 117(6)$ & & \\
\hline Q9QUR7 & 61 & Peptidyl-prolyl cis-trans isomerase NIMA-interacting 1 (PIN1) & $\Delta 111(6)$ & & \\
\hline P48962 & 59 & Adenine nucleotide translocatase-1 (ANT1) & $\bar{\nabla} 29(5)$ & & \\
\hline Q8CEN8 & 64 & Ubiquinol-cytochrome c reductase binding protein (UQCRBP) & $\Delta 40$ (4) & & \\
\hline Q9DC69 & 54 & NADH-ubiquinone oxidoreductase 39 kDa subunit (NDUFA9) & $\nabla 53(4)$ & & \\
\hline Q66HF1 & 67 & NADH dehydrogenase (ubiquinone) Fe-S protein 1 (NDUFS1) & & $\Delta 35(5)$ & $\nabla 49(5)$ \\
\hline Q66HF1 & 77 & NADH dehydrogenase (ubiquinone) Fe-S protein 1 (NDUFS1) & & & $\nabla 28(4)$ \\
\hline $19526814^{*}$ & 87 & NADH dehydrogenase (ubiquinone) flavoprotein 1 (NDUVF1) & & & $\nabla 26(4)$ \\
\hline Q60932 & 71 & Voltage-dependent anion channel 1 (VDAC1) & & & $\nabla 68(5)$ \\
\hline Q60932 & 90 & Voltage-dependent anion channel 1 (VDAC1) & & & $\Delta 161(4)$ \\
\hline Q60930 & 71 & Voltage-dependent anion channel 2 (VDAC2) & & & $\nabla 68(5)$ \\
\hline Q64521 & 78 & Glycerol-3-phosphate dehydrogenase 2 (GPD2) & & & $\nabla 40(5)$ \\
\hline P67778 & 83 & Prohibitin (PHB) & & & Mobility variant (6) \\
\hline $12963799^{*}$ & 88 & ATPase, $\mathrm{H}+$ transporting, $\mathrm{V} 1$ subunit D (ATP6V1) & & & $\nabla 39(4)$ \\
\hline P10649 & 90 & Glutathione S-transferase, mu 1 (GSTM1) & & & $\Delta 161(4)$ \\
\hline \multicolumn{6}{|c|}{ C. Proteins involved in synapse function/vesicular transport } \\
\hline 088935 & 36 & Synapsin I (SYN1) & $\nabla 67(5)$ & & $\Delta 36(4)$ \\
\hline 088935 & 37 & Synapsin I (SYN1) & $\Delta 125(5)$ & & \\
\hline 088935 & 38 & Synapsin I (SYN1) & $\Delta 85(6)$ & & \\
\hline 088935 & 39 & Synapsin I (SYN1) & $\nabla 38(6)$ & & \\
\hline 088935 & 40 & Synapsin I (SYN1) & $\nabla 64$ (5) & & \\
\hline 088935 & 41 & Synapsin I (SYN1) & $\nabla 64(5)$ & & \\
\hline O88935 & 42 & Synapsin I (SYN1) & $\nabla 73(4)$ & & \\
\hline 088935 & 86 & Synapsin I (SYN1) & & & $\Delta 35$ (4) \\
\hline Q64324 & 85 & Syntaxin binding protein 2 (STXBP2) & & & $\nabla 47(5)$ \\
\hline P20172 & 47 & Clathrin-associated adaptor complex AP-2 miu2 chain (CLAPM1) & $\nabla 59(6)$ & & \\
\hline Q61644 & 14 & Protein kinase $C$ and casein kinase substrate in neurons (PACSIN1) & $\nabla 56(5)$ & & \\
\hline $34996507^{*}$ & 1 & AP1 gamma subunit binding protein 1; EST AF007009 (AP1GBP1) & $\nabla 33(5)$ & & \\
\hline Q7TMK9 & 5 & Heterogeneous nuclear ribonucleoprotein Q (HNRNPQ) & $\Delta 250$ (5) & & \\
\hline Q7TMK9 & 46 & Heterogeneous nuclear ribonucleoprotein $\mathrm{Q}$ (HNRNPQ) & $\bar{\nabla} 64(6)$ & & \\
\hline Q9JLB0 & 12 & MAGUK p55 subfamily member 6 (MPP6) & $\Delta 100(5)$ & & \\
\hline \multicolumn{6}{|c|}{ D. Proteins involved in neuronal migration, axon growth and guidance } \\
\hline 088809 & 50 & Doublecortin (DCX) & $\nabla 39(5)$ & & \\
\hline O88809 & 51 & Doublecortin (DCX) & $\nabla 39$ (5) & & \\
\hline P06837 & 15 & Neuromodulin (GAP43) & $\nabla 92(5)$ & & \\
\hline P50396 & 4 & Rab GDP dissociation inhibitor alpha (RABGDI1) & $\nabla 46(6)$ & $\nabla 45(4)$ & $\nabla 62(5)$ \\
\hline Q99PT1 & 26 & Rho GDP-dissociation inhibitor 1 (RHOGDI1) & $\Delta 44$ (6) & $\Delta 31(4)$ & $\Delta 192(5)$ \\
\hline 008553 & 6 & Collapsin response mediator protein 2 (CRMP2) & A $241(5)$ & & \\
\hline 008553 & 7 & Collapsin response mediator protein 2 (CRMP2) & $\Delta 200$ (5) & & \\
\hline 008553 & 8 & Collapsin response mediator protein 2 (CRMP2) & $\Delta 257$ (5) & & \\
\hline O08553 & 9 & Collapsin response mediator protein 2 (CRMP2) & $\Delta 149(5)$ & & \\
\hline 008553 & 10 & Collapsin response mediator protein 2 (CRMP2) & $\Delta 100$ (5) & & \\
\hline Q8IXW6 & 11 & Collapsin response mediator protein 4 (CRMP4) & $\Delta 500$ (5) & & $\Delta 132(5)$ \\
\hline
\end{tabular}




\begin{tabular}{|c|c|c|c|c|c|}
\hline \multirow[b]{2}{*}{$\begin{array}{l}\text { Accession } \\
\text { number }\end{array}$} & \multirow[b]{2}{*}{$\begin{array}{c}\text { Spot } \\
\text { number }\end{array}$} & \multirow[b]{2}{*}{ Protein } & \multicolumn{3}{|c|}{ Quantitative changes (\%) } \\
\hline & & & $\begin{array}{c}\mathrm{P7} \\
\text { acute }\end{array}$ & $\begin{array}{c}\text { P14 } \\
\text { after } 1 \text { week }\end{array}$ & $\begin{array}{c}\text { P35 } \\
\text { after } 4 \text { weeks }\end{array}$ \\
\hline P05216 & 4 & Tubulin alpha-6 chain (TUBA6) & $\nabla 46(4)$ & & \\
\hline $\mathrm{P} 14873$ & 89 & Microtubule-associated protein 1B (MAP1B) & & & $\Delta 54(4)$ \\
\hline P10637 & 49 & Microtubule-associated protein tau type 2 (MAP2) & $\nabla 56(5)$ & & \\
\hline Q80X35 & 44 & Similar to microtubule-associated protein 2 (SimMAP2) & $\nabla 54(5)$ & & \\
\hline Q80X35 & 45 & Similar to microtubule-associated protein 2 (SimMAP2) & $\nabla 100(5)$ & & \\
\hline Q9CQL8 & 29 & Myosin regulatory light chain (MLC) & $\Delta 217(5)$ & & \\
\hline $33469051^{*}$ & 90 & Tubulin polymerization-promoting protein (TPPP) & & & $\mathbf{\Delta} 35(4)$ \\
\hline P18760 & 91 & Cofilin 1 (CFL1) & & & $\nabla 33(5)$ \\
\hline \multicolumn{6}{|c|}{ E. Other proteins } \\
\hline P11499 & 2 & Heat shock protein 90-beta (HSP84) & $\mathbf{\Delta} 19(4)$ & $\nabla 65(5)$ & $\nabla 78(5)$ \\
\hline P11984 & 11 & T complex polypeptide 1 (TCP1) & $\mathbf{\Delta} 500(5)$ & & \\
\hline $\mathrm{P} 43404$ & 13 & Tyrosine-protein kinase ZAP-70 (ZAP70) & $\bar{\nabla} 19(4)$ & & $\nabla 27(5)$ \\
\hline P14701 & 24 & Similar to translationally controlled tumor protein (TPT1) & $\Delta 34(4)$ & & \\
\hline O35479 & 48 & Heterogeneous nuclear ribonucleoprotein G (HNRNPG) & $\nabla 59(4)$ & & \\
\hline Q9CZB7 & 52 & $\begin{array}{l}\text { Protein kinase, interferon inducible double stranded RNA dependent } \\
\text { activator (PRKRA) }\end{array}$ & $\Delta 213(5)$ & & \\
\hline Q9CZB7 & 53 & $\begin{array}{l}\text { Protein kinase, interferon inducible double stranded RNA dependent } \\
\text { activator (PRKRA) }\end{array}$ & $\nabla 56(4)$ & & \\
\hline O35129 & 55 & Repressor of estrogen receptor activity (REA) & $\nabla 100(4)$ & & \\
\hline Q13442 & 58 & PDGFA associated protein 1 (PDAP1) & $\nabla 57(5)$ & & \\
\hline Q9CQE5 & 60 & Regulator of G-protein signalling 10 (RGS10) & $\nabla 36(5)$ & & \\
\hline $34098931^{*}$ & 81 & Calbindin 2 & & & $\nabla 34(4)$ \\
\hline Q8BQK8 & 70 & Purine rich element binding protein $B$ & & $\Delta 78(5)$ & \\
\hline P08113 & 76 & Glucose-regulated protein 94 kDa (GRP94) & & & $\nabla 33(5)$ \\
\hline Q9CY54 & 62 & Hemoglobin beta adult major chain (HBB-B1) & $\nabla 38(4)$ & $\nabla 61(5)$ & \\
\hline Q9CY54 & 63 & Hemoglobin beta adult major chain (HBB-B1 & $\nabla 46(5)$ & & \\
\hline Q9CY10 & 65 & Hemoglobin alpha adult chain 1 (HBA-A1) & $\nabla 27(5)$ & $\nabla 57(4)$ & \\
\hline $16741237^{*}$ & 18 & RIKEN cDNA $2300004 C 15$ & $\Delta 80(5)$ & & \\
\hline $16741237^{*}$ & 19 & RIKEN cDNA 2300004C15 & $\nabla 60(4)$ & & \\
\hline $37360010^{\star}$ & 68 & mKIAA0616 protein & & $\nabla 29(4)$ & \\
\hline
\end{tabular}

For each altered protein, an abbreviation, the 2-DE spot number, the SWISS-PROT/TrEMBL accession number or NCBI reference number $\left({ }^{\star}\right)$, the median percentage of spot intensity difference in affected mouse pairs and, in brackets, the numbers of mouse pairs with alterations in the intensity of a specific spot $\left({ }^{\star *}\right)$ are presented. Triangles pointed upward and downward indicate an increase or decrease, respectively, of a spot intensity in hyperoxia-treated mice as compared to their untreated littermates

in the balance of protein phosphorylation and dephosphorylation is suggested by the observed acute increase of phosphorylated protein phosphatase $2 \mathrm{~A}$ inhibitor (2IPP2A) or by a dysregulation of annexin A5 (ANX5). Furthermore, a decrease of programmed cell death 5 (PDCD5) protein and phosphoprotein enriched in astrocytes 15 (PEA15), a protein that has been associated with astrocyte protection against tumor necrosis factor (TNF)-induced apoptosis, was detected. In adolescent mice, we observed a reduction of peroxiredoxin 3 and an increase of superoxide dismutase, but no significant alterations in proteins associated with apoptosis or cell growth (data not shown).

\section{Histological features}

Consistent with the results of the proteome analysis, exposure of 6-day-old rodents to a high inspiratory oxygen concentration of $80 \%$ over a period of $12 \mathrm{~h}$ increased the rate of cell death in the developing brain acutely as revealed by TUNEL staining and immunohistochemical staining with an antibody against the active subunit of caspase-3 (Figure 3). A significant increase of activated caspase-3 following hyperoxia was confirmed through Western blotting of brain proteins (Figure 3). In previous studies, we demonstrated that hyperoxia-induced cell death displays morphological features similar to physiological apoptotic cell death and occurs in a disseminated fashion throughout the immature rat brain. ${ }^{9}$ The extent of brain damage depends both on the duration of an exposure to high oxygen levels and on the age of hyperoxiaexposed rodents; vulnerability is significantly increased in neonatal rodents and subsides by $\mathrm{P} 14 .^{9}$

To further confirm that the observed changes in brain proteome reflect increased production of ROS and resulting oxidative stress, we examined brains of 7-day-old mice following hyperoxia or normoxia (controls) for proteins modified by ROS. Analysis of brain lysates revealed elevated levels of protein carbonyls, a general marker of oxidative stress (Figure 4). Furthermore, we had previously reported a significant increase of oxidized glutathione and an increase in the ratio of oxidized to reduced glutathione in the brains of rodents exposed to hyperoxia compared to those kept at room air, findings that are consistent with oxidative stress. ${ }^{9}$

\section{Changes in proteins associated with synaptic function and vesicle trafficking}

Following hyperoxia, we detected an acute downregulation of five and an upregulation of two isospots of synapsin 1 (SYN 1), a protein that regulates nerve terminal function in mature 
a TUNEL
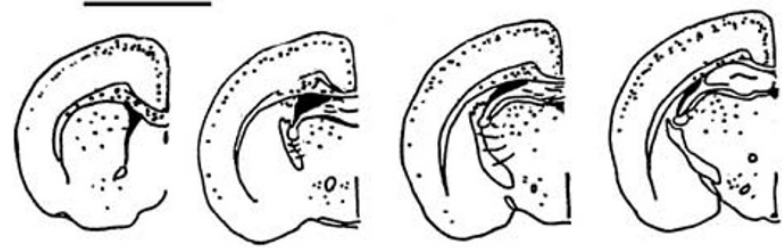

b
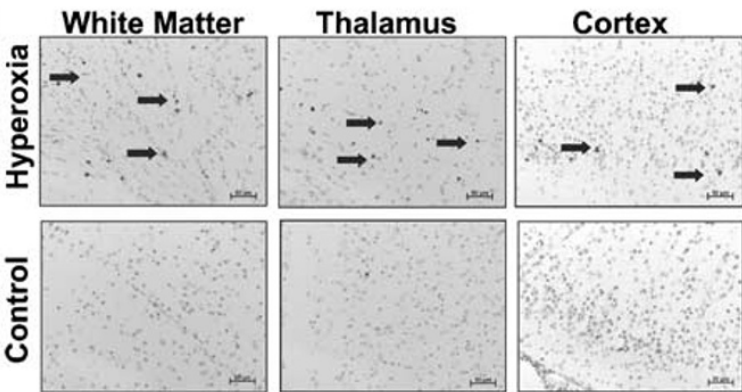

C

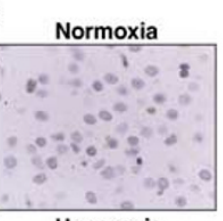

Hyperoxia

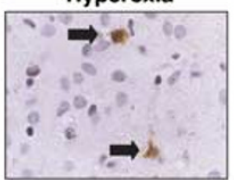

d

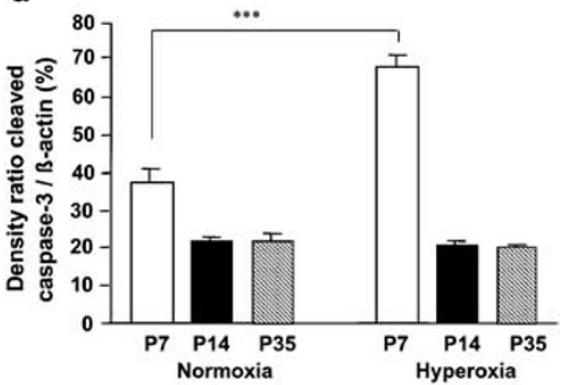

Figure 3 Features of hyperoxia-induced brain damage in infant mice. (a) Schematic illustration of the distribution of TUNEL-positive cells in the brains of P7 mice subjected to $12 \mathrm{~h}$ of hyperoxia. Dotted areas in coronal brain sections indicate affected brain regions. (b) TUNEL-stained sections of the white matter, thalamus and cortex display TUNEL-positive cells (arrows). There are more TUNEL-positive profiles in the brains of mice exposed to hyperoxia. (c) Immunohistochemical staining for activated caspase-3 in the thalamus of a P7 mouse exposed to normoxia or hyperoxia. Arrows indicate cells that display immunoreactivity for activated caspase-3. (d) Western blot analysis for activated caspase-3 performed at P7, P14 and P35 confirmed the acute increase of activated caspase- 3 in the brains of mice exposed to hyperoxia at P7 as compared to littermate controls. Bars represent normalized mean ratios of caspase-3/ $\beta$-actin \pm S.E.M. ( $n=6$ per group). Statistical analysis by means of Student's $t$-test revealed that hyperoxia lead to a significant increase of protein levels of activated caspase- 3 at P7 $\left({ }^{* *} P<0.001\right)$. At the ages of P14 and P35 there was no difference between the hyperoxia and normoxia groups

synapses and also affects axonogenesis and synaptogenesis, and a dysregulation of heterogeneous nuclear ribonucleoprotein Q (hnRNP-Q), a protein which modifies exocytosis, vesicle trafficking and mRNA dynamics. Furthermore, dysregulation of $\mathrm{Rab}$ and Rho GDP dissociation inhibitors (Rab GDI, Rho GDI), clathrin-associated adaptor complex AP-2 (CLAPM1), AP1 gamma subunit binding protein 1 (AP1GBP1), protein kinase $C$, casein kinase substrate in neurons protein 1 (PACSIN1), syntaxin binding protein 2 (STXBP2) and MAGUK p55 subfamily member 6 (MPP6) was detected (Table 1, Figure 2c). Hyperoxia generated no detectable alterations in proteins associated with synaptic function or vesicle trafficking in adolescent mice.
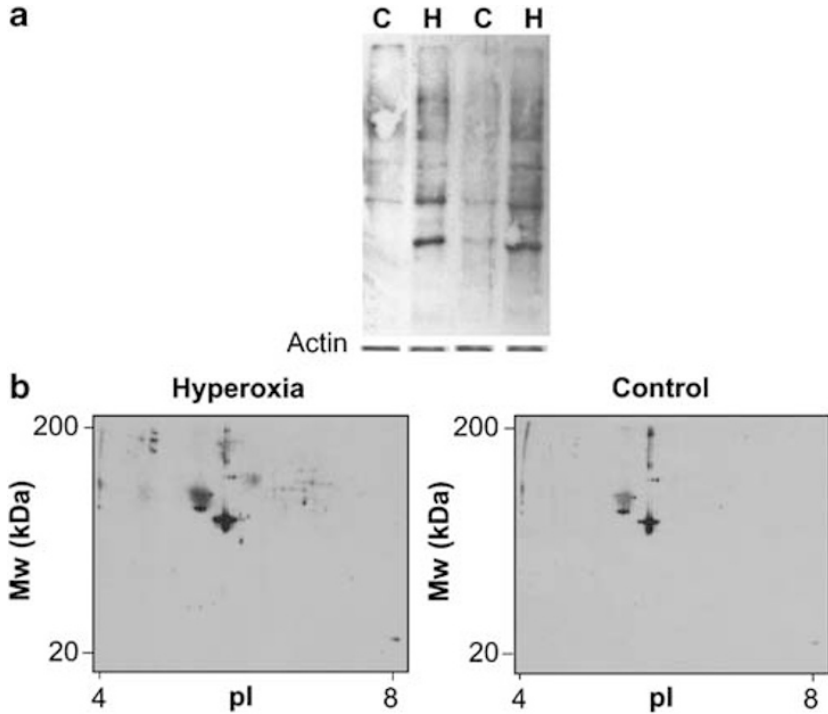

Figure 4 Increased ROS damage of immature rodent brain proteins upon hyperoxia. (a) Analysis of brain lysates from hyperoxia-treated $(\mathrm{H})$ and control mice (C) following SDS-PAGE reveals increased levels of protein carbonyls following hyperoxia. Incubation of the same blots with anti-actin antibody confirms equivalent loading of proteins in each lane. (b) Oxidized proteins were also detected following protein separation according to their $\mathrm{pl}$ in the first and their $\mathrm{Mw}$ in the second dimension by 2-DE

\section{Changes in proteins associated with neuronal migration, axon growth and guidance}

In response to hyperoxia, the abundance of doublecortin (DCX) and neuromodulin (GAP43) was acutely reduced (Figure 2d). In addition, an acute and long-term decrease of Rab GDI 1, an increase of Rho GDI 1 and a significant acute and/or long-term increase of Rho GTPase downstream effectors collapsin response mediator proteins (CRMP)-2 and CRMP-4 was found.

To confirm that the observed changes in the 2-DE gels following hyperoxia can be reproduced by other techniques, we applied DCX immunohistochemistry to visualize DCX reduction in rodent brain on $\mathrm{P} 7$ after hyperoxia exposure at P6. DCX immunostaining was reduced diffusely within cell somata in the forebrain and the cerebellum of rodents in response to hyperoxia as compared to age-matched control animals (Figure 5). The acute reduction of DCX following hyperoxia was further confirmed by Western blotting (Figure 5)

DCX is highly expressed in migrating and/or differentiating neurons and its decreased expression suggests possible impact of hyperoxia on neuronal differentiation. To analyze whether hyperoxia may affect progenitor cells in the immature mouse brain, we analyzed the abundance of the progenitor cell-specific protein nestin at P7, P14 and P35 following hyperoxia at $\mathrm{P} 6$. Interestingly, we detected an acute increase of nestin in the brains upon exposure of immature mice to high oxygen levels by means of Western blotting (Figure 5), suggesting that hyperoxia affects neuronal progenitor cells in a way that is different from its effect on young differentiated neurons. 

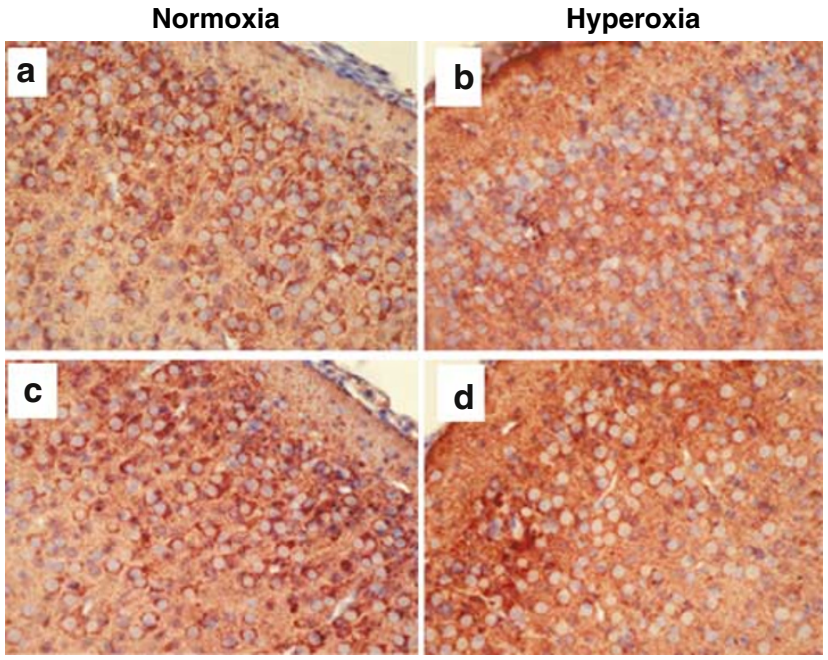

e
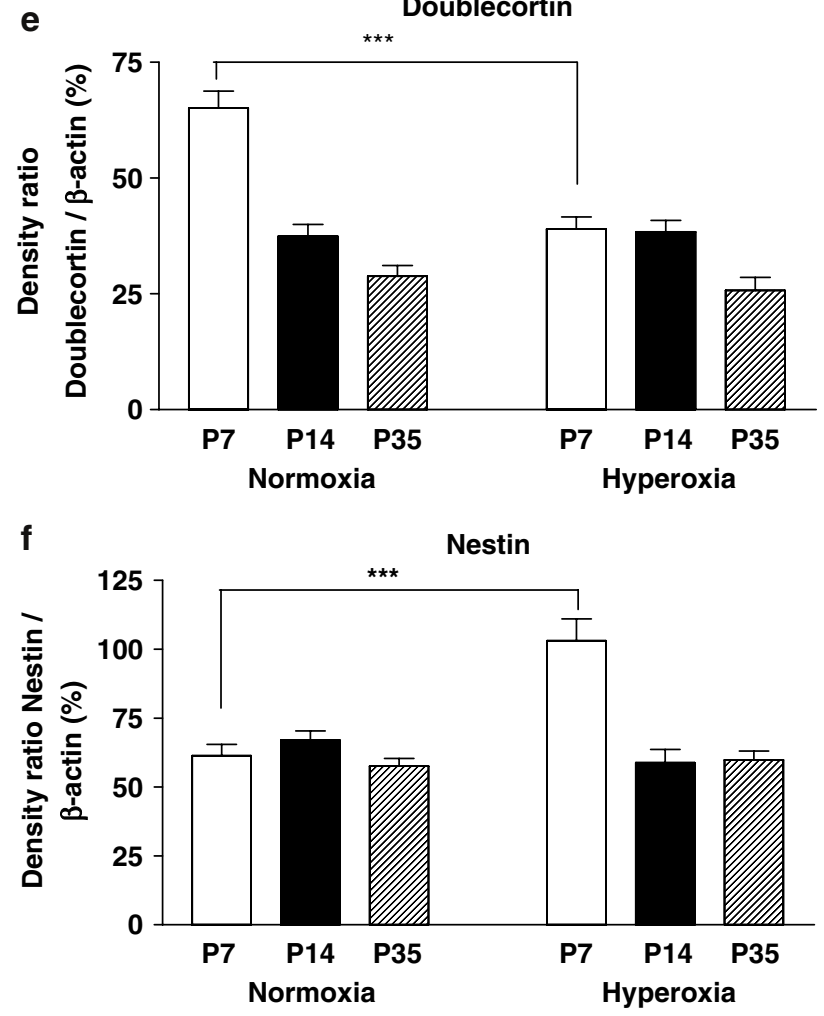

Figure 5 Reduction of DCX in the forebrain and increase of nestin following hyperoxia. (a-d) Representative light micrographs showing immunostaining for $\mathrm{DCX}$ in the frontal $(\mathbf{a}, \mathbf{b})$ and parietal cortex $(\mathbf{c}, \mathbf{d})$ in normoxia $(\mathbf{a}, \mathbf{c})$ and hyperoxia (b, d) exposed P7 rats. DCX staining is positive in neuronal somata and less intense in rats exposed to a hyperoxic environment on P6. Original magnification $\times 40$. The acute reduction of DCX, a protein strongly expressed in migrating and differentiating neurons, was confirmed by Western blotting (e). The increased abundance of the progenitor cell-specific protein nestin (f) suggests that hyperoxia also affects neuronal and glial progenitor cells. Bars in (e) and (f) represent normalized mean ratios of doublecortin/ $\beta$-actin or nestin/ $\beta$-actin \pm S.E.M. ( $n=6$ per group). Statistical analysis by means of Student's $t$-test revealed that hyperoxia lead to a significant decrease of protein levels of DCX at $P 7\left({ }^{* * *} P<0.001\right)$ and an increase in the levels of nestin $\left({ }^{* * *} P<0.001\right)$. At the ages of P14 and P35 there was no effect of hyperoxia on the levels of DCX or nestin

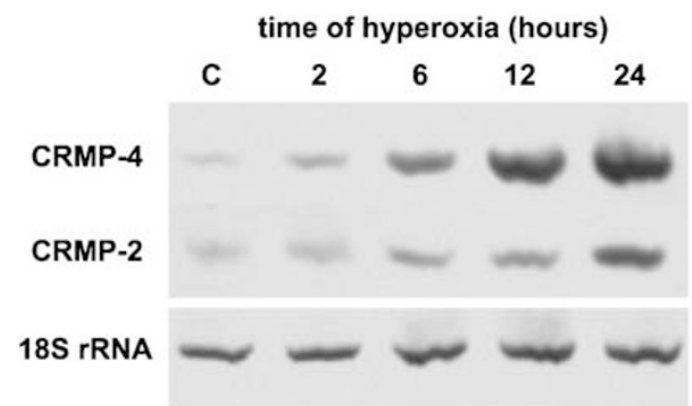

Figure 6 Increase of CRMP2 and $4 \mathrm{mRNA}$ in the retrosplenial cortex following hyperoxia. P6 mice were subjected to hyperoxia $(80 \%)$ or normoxia. Semiquantitative RT-PCR analysis performed 2, 6, 12 and $24 \mathrm{~h}$ after the initiation of hyperoxia on samples from the retrosplenial cortex demonstrate a strong, hyperoxia-induced increase of CRMP2 and CRMP4 mRNA levels (internal standard 18S rRNA). Gels are representative of a series of three determinations

Growth cone guidance and migration may be influenced by the observed acute and long-term decrease of Rab GDI 1 and increase of Rho GDI 1 and a significant acute and/or long-term increase of Rho GTPase downstream effectors CRMP-2 and CRMP-4 (Table 1; Figure 2d). To confirm changes seen in 2DE gels, we applied reverse transcription polymerase chain reaction (RT-PCR) analysis of samples from retrosplenial cortex. In accordance with the changes seen on 2-DE gels, we detected a progressive increase of CRMP-2 and CRMP-4 mRNA levels 2, 6, 12 and $24 \mathrm{~h}$ following the initiation of hyperoxia (Figure 6).

Several proteins dysregulated acutely and/or as a long-term effect of hyperoxia have been associated with growth and energy metabolism (Table 1). None of these protein changes were identified in adolescent mice, thus strongly supporting their specificity for the infantile period.

The effects of high oxygen levels on brain proteins appear to be age-dependent as they did not occur in mice exposed to high oxygen levels at an age beyond the period of rapid brain growth. In the older animals, we detected a significant dysregulation of two proteins associated with oxidative stress (peroxiredoxin 3, superoxide dismutase), increased levels of beta actin and decreased levels of hemoglobin alpha chain (data not shown).

\section{Discussion}

In the present study, we analyzed acute (P7) and long-term (P14, P35) changes of the brain proteome in mice subjected to hyperoxia on P6. We aimed to explore the range of proteins/ protein pathways engaged in hyperoxia-induced pathological modulation of maturation processes in the developing brain. Our results, obtained by 2-DE electrophoresis and partly confirmed with use of other techniques, indicate that hyperoxia in early development leads to reproducible alterations in the brain proteome. Hyperoxia-induced oxidative stress causes widespread apoptotic cell death in the infant rodent brain. Furthermore, oxidative stress may influence certain developmental events including synaptic function, neuronal differentiation and axonal arborisation in an agedependent fashion. 
Through a comparison of brain proteomes of infant mice exposed to hyperoxia with those of control littermates we detected consistent acute and long-term changes in the abundance of 48,12 and 23 proteins at P7, P14 and P35 (67, 12 and 26 protein spots), respectively. At 1 week following hyperoxia, we observed very dynamic alterations in protein synthesis with some protein spots still or already altered in some mice while others show no alteration in protein abundance, a finding that in part explains the lower number of reproducibly altered proteins at P14. Moreover, the alterations observed in infant mice did not occur in juvenile mice exposed to high oxygen levels every other day from P28 to P34, that is, at an age past the period of rapid brain growth (Figure 1, Table 1). Thus, brain protein alterations in mice exposed to hyperoxia in infancy appear to be effects specific for the early stage of brain development.

Protein dysregulation occurred primarily in the acute phase of hyperoxia and resolved within 1 (P14) to 4 weeks (P35). Thereafter, alterations of seven proteins persisted for at least 4 weeks (tyrosine 3-monooxygenase/tryptophan 5-monooxygenase activation protein (14-3-3) $\beta$, SYNI, Rab GDI 1, Rho GDI 1, CRMP-2, CRMP-4 and HSP84; see Table 1). Surprisingly, late changes of 13 previously unaltered proteins appeared 4 weeks after hyperoxia (14-3-3e, 14-3-3g, DUVF1, voltage-dependent anion channel 1 (VDAC1), CDAC2, GDP2, ATPase, $\mathrm{H}+$ transporting, V1 subunit D (ATP6V1), glutathione S-transferase, mu 1 (GSTM1), MAP1B, tubulin polymerization-promoting protein (TPPP), cofilin (CFL) 1, calbindin 2, GRP94; see Table 1). While acute alterations can be explained as direct effects of hyperoxia on cell metabolism (e.g. apoptosis), protein changes that persist or even occur later in development indicate long-term disruption of brain function/morphology and/or ongoing reorganization processes. Hyperoxia causes acute functional and morphological changes of the immature brain. ${ }^{8-10}$ In addition, acute functional and morphological changes may induce further functional and morphological changes in the period of rapid brain development and thereby cause an irreversible damage in the adult brain.

Differences in spot intensity detected on 2-DE gels in response to hyperoxia may result (i) from a change in total concentration of a protein (spot family) or (ii) from a change of one or several isospots within a spot family; small differences between experimental groups may remain undetected on account of the limited dynamic range of silver staining. We did detect opposing changes within isospots of six proteins: 14-3$3 \beta$, PEA15, hnRNP-Q, SYN1, VDAC1 and RIKEN cDNA 2300004C15. Co- and post-translational modifications such as alternative splicing and phosphorylation established, for example, 38 isospots located in two horizontal spot series that were identified as SYN1. ${ }^{15}$ Immediately after hyperoxia, the relative concentration of five SYN1 isospots was reduced by factors of 1.4-1.7, while that of two SYN1 isospots was increased 1.9- to 2.3-fold. At 4 weeks following hyperoxia, a further SYN1 isospot appeared that was altered. Such a differential regulation of a protein phenotype may contribute to fine-tuning and adjustment of a pathway. By our approach, we typically identified one or a few members of a distinct pathway that may be engaged in the pathogenesis of oxidative-stress mediated brain damage. This approach does not facilitate the detection of all members of a particular pathway; this is partly due to an under representation of low-abundance, hydrophobic, very acidic or basic as well as very low- or highmolecular mass proteins in 2-DE gels.

Acute and long-term alterations of brain proteins detected in this study indicate that an exposure of infant rodents to high oxygen levels not only result acutely in oxidative stress and an increased rate of apoptosis in their brains, but may also elicit long-term alterations in cell growth and differentiation, synaptic function, neuronal migration and axonal arborization (Table 1).

\section{Oxidative stress, apoptosis and growth}

Acute and long-term changes in proteins that can be linked to oxidative stress and/or apoptosis were detected. An acute decrease of oxidative enzyme activity in response to oxidative stress may originate from an increased enzyme consumption to prevent oxidative damage. ${ }^{16}$ In accordance, analysis of brain tissue following hyperoxia revealed elevated levels of protein carbonyls, that is, proteins modified by ROS (Figure 4). Also, we have previously described a significant increase of oxidized glutathione and an increase in the ratio of oxidized to reduced glutathione in immature rodent brains exposed to hyperoxia compared to those kept at room air. ${ }^{9}$ As a secondary effect, the observed acute depletion of peroxiredoxin 2 may decrease the activity of redox-sensitive proteins. ROS-induced dephosphorylation of apoptosis signal-regulating kinase 1 (ASK1), for example, leads to an activation of this protein through a phosphorylation-dependant dissociation of the ASK1/14-3-3 complex. ${ }^{17}$ The dysregulation of 14-3-3 protein polypeptides detected in response to hyperoxia may similarly mediate acute oxidative stressinduced apoptosis by its dissociation from the ASK1/14-3-3 complex and subsequent ASK1 activation and may lead to an acute and/or long-term induction of further pathways that are controlled by 14-3-3-ligand interactions. ${ }^{18}$ Cell death may also be triggered by a shift in the balance of protein phosphorylation and dephosphorylation through the observed acute increase of phosphorylated 2IPP2A or by a dysregulation of ANX5, an early-stage apoptosis marker. ${ }^{19,20} \mathrm{~A}$ decrease of PDCD5 protein may either be caused by acutely increased rates of apoptosis (protein depletion) or may be the result of a primary antiapoptotic effect. ${ }^{21,22}$ Decreased levels of PEA-15 protein have been associated with astrocyte protection against TNF-induced apoptosis. ${ }^{23}$ In addition to these differentially regulated proteins that have been linked to apoptosis and oxidative stress and are accompanied by morphological correlates, ${ }^{8-10}$ a dysregulation of proteins associated with cell growth and energy metabolism suggests that these biological processes are also affected by an exposure to high oxygen levels during the brain growth spurt period (Table 1; Figure 2b).

\section{Synaptic function and vesicle trafficking}

In the mature brain, oxidative stress modulates neuronal excitability and morphological features of synapses: ${ }^{24,25}$ while low levels of hydrogen peroxide seem to prime synapses and induce long-term potentiation (LTP), high levels of ROS have 
detrimental effects on neuronal plasticity and suppress LTP in hippocampal slices of rats and mice. ${ }^{24}$ Following hyperoxia, we detected an acute and long-term dysregulation of SYN1, a protein that regulates nerve terminal function in mature synapses and also affects axonogenesis and synaptogenesis. $^{26}$ While the acute dysregulation of SYN1 may be interpreted as secondary to a depletion of synaptic vesicles, the increase in abundance of two isospots of this protein 4 weeks following hyperoxia suggests a long-term disruption of normal synaptic function. The observed change of hnRNP-Q may modify exocytosis, vesicle trafficking and mRNA dynamics. $^{27}$ Endocytosis, on the other hand, and/or vesicle trafficking can be affected by the observed dysregulation of Rab and Rho GDI, CLAPM1, AP1GBP1, PACSIN1 and STXBP2. ${ }^{28}$ Supported by previous reports on oxidative stress-induced modulation of synapses, the changes in abundance of proteins associated with exocytosis, endocytosis and vesicle trafficking can be associated with an acute and long-term synaptic dysfunction in developing rodent brains in response to hyperoxia (Table 1, Figure $2 \mathrm{c}$ ).

\section{Neuronal differentiation, migration, axonal growth and guidance}

Neuronal circuit development depends not only on synaptogenesis and synaptic function but also on cell migration and the navigation of axons and dendrites to their targets. ${ }^{29} \mathrm{DCX}$ and GAP43 protein concentrations were acutely reduced due to hyperoxia. Decreased levels of DCX in 2-DE gels following hyperoxia were verified by immunohistochemistry and Western blotting. Since DCX is strongly expressed in migrating and differentiating neurons, ${ }^{30}$ this biochemical finding may be associated with an acute decrease of neuronal migration and/ or differentiation. Interestingly, we observed an increase of the progenitor cell-specific protein nestin following hyperoxia, indicating that oxidative stress may have different effects on neuronal progenitors and young differentiating neurons in the immature mouse brain.

GAP43 is expressed at the tips of growth cones of migrating neurons; ${ }^{31}$ downregulation of this protein in dentate granule cells of rat models of mesial temporal lobe epilepsy was accompanied by mossy fiber sprouting in the inner molecular layer of dentate granule cells and by an extensive neuronal loss $24 \mathrm{~h}$ after status epilepticus. ${ }^{31}$

Growth cone guidance is accomplished by regulation of (i) polymerization/depolymerization of actin, microtubule and cytoskeleton-associated components such as microtubuliassociated proteins, (ii) transmembrane adhesion and signaling molecules, (iii) second messenger pathways such as the main regulators of actin and microtubule dynamics, Rho family small GTPases and (iv) proteins involved in anterograde and retrograde transport such as myosin. ${ }^{29}$ Molecular guidance cues directly or indirectly control cytoskeleton dynamics by modulating the function of Rho family small GTPase regulators such as guanine nucleotide exchange factors (GEFs), GTPase-activating proteins (GAPs) and guanine nucleotide dissociation inhibitors (GDIs). ${ }^{32}$ Therefore, growth cone guidance may be influenced by the acute and long-term decrease of Rab GDI 1 and increase of Rho
GDI 1; both proteins bind to the GDP form of Rho GTPases, slow the rate of GDP dissociation from Rho GTPases and thereby decrease the activity of these proteins. ${ }^{32}$ The opposite regulation of these inhibitors (increase versus decrease) is explicable taking into account that they control different Rho GTPases, which again interact competitively with each other and cause downstream effects. ${ }^{32}$

GTP-bound Rho family GTPases modulate cytoskeletal morphology through a wide variety of effector molecules. ${ }^{32-35}$ As a further indication for aberrant growth cone guidance following hyperoxia, we observed a significant acute and/or long-term increase of Rho GTPase downstream effector CRMP-2 and CRMP-4 mRNA and protein levels (Table 1; Figures $2 d$ and 5). The function of CRMPs, proteins initially identified as mediators of semaphorin3A/collapsin-induced growth-cone collapse, is crucial for axonal growth and branching, determination of axon-dendrite fate, establishment of neuronal polarity and kinesin I-dependent transport of proteins to growth cones. ${ }^{33-35}$ Consistent with previous studies, ${ }^{35}$ we observed a strong expression of CRMP-2 and CRMP-4 proteins in C57BL/6 mouse brain at early stages of development and a massive reduction following the period of rapid brain growth within the first three postnatal weeks (data not shown). In the adult, a re-expression of CRMP-4 has been detected during axonal regrowth following axotomy, ${ }^{35}$ and CRMP-2 overexpression in cultured dorsal root ganglions accelerated the regeneration of injured neurons. ${ }^{36}$ On the other hand, an overexpression of CRMP-2 in primary cultured hippocampal neurons disrupted neuronal polarity and induced the formation of supernumerary axons. ${ }^{37}$ Thus, mechanisms underlying extracellular neurite guidance cues and growth cone dynamics during development may be implicated in neuron regeneration following hyperoxia-induced neurodegeneration. However, the fast upregulation of CRMP proteins in the developing rodent brain upon hyperoxia may also prove detrimental and cause CNS damage by a formation of aberrant axons and/or a loss of neuronal polarity. We also observed an acute and long-term dysregulation of further downstream cytoskeleton targets such as microtubule-associated proteins, tubulin and myosin (Table 1, Figure 2d). These cytoskeletal structure proteins are targets for oxidative stress; they may also represent markers of neuronal density, synaptosomal structure and dendritic spines. ${ }^{38}$ The findings discussed above and the change of brain proteins associated with neuronal migration and axonal outgrowth in our rodent model outlined earlier indicate hyperoxia-induced morphological alterations like the formation of aberrant axons and dendrites and/or a loss of neuronal polarity. Anatomical abnormalities such as mossy fiber sprouting and the formation of additional and abnormal synaptic connections have been observed in response to repeated early-life seizures. ${ }^{39}$ These effects of oxygen on brain proteins did not occur in mice exposed to high oxygen levels at an age beyond the period of rapid brain growth.

While acute brain protein alterations within the period of rapid brain growth most likely represent direct effects of elevated oxygen concentrations on cell metabolism, sustained or newly evolved differences in brain protein phenotypes 4 weeks after the exposure to hyperoxia may constitute secondary changes such as irreversible morphological 
alterations (a possibly ongoing shift in normal developmental program) and/or reorganization events. In comparison to the adult brain, toxic oxygen levels disturb a vulnerable and developing system in the immature rodent in which the cellular phenotypes, protein concentrations, protein compositions and interactions change rapidly according to a predetermined developmental program. So far, little is known about the effects of oxidative stress on dynamic processes in the developing brain. The characterization of these age-associated protein alterations and of their effect on brain development is thus of critical importance. Our results demonstrate that comparative analysis of the brain proteome facilitates insight into the nature of developmental events that may be disrupted by hyperoxia and perhaps also by other developmental insults. In the case of hyperoxic exposure of infant rodents, impairment beyond that of oxidative stressinduced acute apoptotic neurodegeneration became evident. These effects did not occur in mice exposed to high oxygen levels at an age beyond the period of rapid brain growth. Our findings indicate that in the developing brain, hyperoxia may acutely alter synaptic transmission, inhibit cell growth and differentiation and induce abnormal axonal outgrowth. Ongoing studies will explore functional and morphological aspects of these effects, suspected on the basis of comparative analysis of the brain proteome.

\section{Materials and Methods}

\section{Animal experiment}

Animal experiments were performed according to institutional guidelines. C57BL/6 6-day-old mice (Charles River, Sulzfeld, Germany) were exposed to an inspiratory oxygen concentration of $80 \%$ in an oxygen chamber for a period of $12 \mathrm{~h}$ with their dams, killed by an overdose of intraperitoneal chloral hydrate immediately (P7; $n=6)$, 1 week (P14; $n=6)$, or 4 weeks (P35; $n=7$ ) after hyperoxia, respectively, transcardially perfused with heparinized $0.1 \mathrm{M}$ phosphate-buffered saline (PBS) solution and decapitated. To determine whether hyperoxia-induced brain protein changes differ with age, juvenile mice were subjected to hyperoxia for a period of 24 hours at postnatal days P28, P30, P32, P34 and sacrificed at P35 $(n=10)$. An equal number of sex-matched littermates kept at room-air served as controls; body temperature was normal and did not vary significantly between experimental groups. Brains were removed, divided sagittaly into left and right halves, snap frozen in liquid nitrogen and stored at $-80^{\circ} \mathrm{C}$. For optimal reproducibility, brain protein extracts from each of the six sample pairs of mice (hyperoxia and controls) were processed together throughout the 2-DE procedure.

For immunohistochemistry, 6 -day-old Wistar rat pups $(n=6$; BgVV, Berlin, Germany) or C57BL/6 mice (Charles River) were subjected to $12 \mathrm{~h}$ of hyperoxia and killed at P7. For RT-PCR, 6-day-old Wistar rat pups ( $n=6 ; \mathrm{BgVV}$ ) were exposed to hyperoxia for $0,2,6,12$ and $24 \mathrm{~h}$ and killed immediately at the end of treatment. Animals were decapitated and brain tissue was microdissected from the retrosplenial cortex, snap-frozen in liquid nitrogen and stored at $-80^{\circ} \mathrm{C}$. In all experiments an equal number of littermates kept at room air served as controls.

\section{Histology}

For histological analysis, hyperoxia-treated and control mice (TUNEL, caspase-3) or rats (DCX) were anesthetized with an intraperitoneal injection of chloral hydrate $1 \mathrm{~g} / \mathrm{kg}$, transcardially perfused with heparinized $0.01 \mathrm{M} \mathrm{PBS}$ at $\mathrm{pH} 7.4$ and subsequently with $4 \%$ paraformaldehyde in cacodylate buffer at $\mathrm{pH} 7.4$. Following a postfixation time of 3 days at $4{ }^{\circ} \mathrm{C}$, the brains were embedded in paraffin and processed for terminal deoxynucleotidyl transferase-mediated dUTP-biotin nick end-labeling (TUNEL), activated caspase-3 or DCX staining.

TUNEL staining was performed using the ApopTag Peroxidase kit (S 7100, Oncor Appligene, Heidelberg, Germany) according to the protocol supplied by the manufacturer. Briefly, after pretreatment with proteinase $\mathrm{K}$ and quenching of endogenous peroxidase, sections were incubated first in equilibration buffer followed by working strength TdT enzyme (incorporating digoxigenin labelled dUTP nucleotides to free $3^{\prime}-\mathrm{OH}$ DNA termini) for $1 \mathrm{~h}$ at $37^{\circ} \mathrm{C}$. Sections were incubated in stop/wash buffer $\left(30 \mathrm{~min}, 37^{\circ} \mathrm{C}\right)$, in anti-digoxigenin-peroxidase conjugate $(30 \mathrm{~min})$, thereafter with $\mathrm{DAB}$ substrate (Sigma, Deisenhofen, Germany) and lightly counterstained with hematoxylin.

For activated caspase-3 staining, $10 \mu \mathrm{m}$ thick, coronal microtome sections were mounted onto 3-aminopropyltriethoxysilane-coated glass slides (Sigma) and microwaved in $10 \mathrm{mM}$ citrate buffer ( $\mathrm{pH} 6.5)$ at $750 \mathrm{~W}$. Endogenous peroxidase activity was blocked with $0.6 \% \mathrm{v} / \mathrm{v}$ hydrogen peroxide for $15 \mathrm{~min}$. Sections were incubated in normal goat serum for $20 \mathrm{~min}$, in rabbit anti-cleaved caspase-3 monoclonal antibody $(1: 100$, Cell Signaling Technology, Beverly, MS, USA) overnight at $4^{\circ} \mathrm{C}$ and subsequently in secondary IgG antibody (goat anti-rabbit 1:200; Vector Laboratories, Burlingame, CA, USA). Controls were treated with the corresponding blocking peptides. After detection with $A B C$ reagents (standard Vectastain ABC Elite Kit, Vector Laboratories), positive cells were visualized with diaminobenzidine (DAB, Sigma) and lightly counterstained with hematoxylin.

For DCX immunohistochemistry, $10 \mu \mathrm{m}$ thick sagittal microtome sections were mounted onto SuperFrost ${ }^{\circledR}$ Plus glass slides, deparaffinized in xylene and rehydrated in descending ethanol series. The sections were microwaved in $10 \mathrm{mM}$ citrate buffer ( $\mathrm{pH} \mathrm{6.5)}$ ) at $750 \mathrm{~W}$. Endogenous peroxidase activity was blocked with $3 \% \mathrm{v} / \mathrm{v}$ hydrogen peroxide in methanol for $20 \mathrm{~min}$. Sections were incubated in blocking solution with $10 \%$ normal horse serum (Vector Laboratories) containing 1\% albumin from bovine serum (BSA; Sigma) for $30 \mathrm{~min}$ at room temperature and left overnight at $4{ }^{\circ} \mathrm{C}$ with goat polyclonal anti-DCX antibody (1:500; Santa Cruz Biotechnology, Santa Cruz, CA, USA) in $0.1 \%$ BSA. Negative controls were performed by including the peptide immunogen as a competitor of antibody binding according to the manufacturer's instructions. Sections were then incubated with biotinylated horse anti-goat antibody (1:200; Vector Laboratories) in $0.1 \% \mathrm{BSA}$ for $1 \mathrm{~h}$ at room temperature. After detection with $A B C$ reagent for $30 \mathrm{~min}$ at room temperature, positive cells were visualized by incubation with the substrate Vector Nova Red (Vector Laboratories) for 7-8 min, counterstained with hematoxylin for $1 \mathrm{~min}$, subsequently dehydrated in ascending ethanol series, cleared in xylene and mounted with permount.

\section{Protein extraction procedure}

Total protein extracts were prepared from left brain halves by an extraction procedure described previously, with some modifications. ${ }^{40,41}$ In short, frozen brain tissue, 1.6 parts $\mathrm{v} / \mathrm{w}$ of buffer $1(0.11 \mathrm{M}$ CHAPS, $50 \mathrm{mM}$ TRIZMA ${ }^{\circledR}$ Base (Sigma-Aldrich, Steinheim, Germany), $50 \mathrm{mM} \mathrm{KCl}$ and $20 \% \mathrm{w} / \mathrm{v}$ glycerol at $\mathrm{pH} 7.5), 0.08$ parts of protease inhibitor solution I (1 Complete $^{\mathrm{TM}}$ tablet (Roche Applied Science, Mannheim, Germany) dissolved in $2 \mathrm{ml}$ of buffer 1) and 0.02 parts of protease inhibitor solution II (1.4 $\mu \mathrm{M}$ pepstatin $\mathrm{A}$ and $1 \mathrm{mM}$ phenylmethylsulfonyl fluoride in ethanol) were ground to fine powder in a mortar precooled in liquid nitrogen. The 
tissue powder was transferred into a $2 \mathrm{ml}$ tube, quickly thawed and supplied with an average number of 11 glass beads ( 0.034 units of glass beads per combined weight of tissue, buffers and inhibitors in $\mathrm{mg}$ ). Each sample was sonicated 6 times in an ice-cold water bath for $15 \mathrm{~s}$ each, with cooling intervals of $1 \mathrm{~min} 45 \mathrm{~s}$ in between. The homogenate was stirred for $30 \mathrm{~min}$ in the presence of 0.025 parts $\mathrm{v} / \mathrm{w}$ of benzonase (Merck, Darmstadt, Germany) and 0.021 parts v/w $5 \mathrm{mM}$ magnesium chloride in buffer 1 without CHAPS at $4^{\circ} \mathrm{C}$. Subsequently, $6.5 \mathrm{M}$ urea and $2 \mathrm{M}$ thiourea were added, and stirring was continued for $30 \mathrm{~min}$ at room temperature until urea and thiourea were completely dissovled. The protein extract was supplied with 0.1 parts v/w dithiothreitol (Biorad, Munich, Germany), 0.1 parts v/w of ampholyte mixture Servalyte $\mathrm{pH}$ 2-4 (Serva, Heidelberg, Germany), corrected by the amount of urea added (correction factor $=$ sample weight prior to addition of urea/sample weight after addition of urea), and stored at $-80^{\circ} \mathrm{C}$. Protein concentrations were determined using Biorad DC Protein Assay according to the protocol supplied by the manufacturer (Biorad).

\section{2-DE electrophoresis}

We separated brain proteins by large-gel 2-DE as described previously. ${ }^{40,41}$ The gel format was $40 \mathrm{~cm}$ (isoelectric focussing) $\times 30 \mathrm{~cm}$ (SDS-PAGE) $\times 0.75 \mathrm{~mm}$. For isoelectric focusing (IEF) using the mobile ampholyte technique, we applied $6 \mu \mathrm{l}(\sim 20 \mu \mathrm{g} / \mu \mathrm{l})$ protein extract of each sample to the anodic end of an IEF-gel and used a carrier ampholyte mixture to establish a pH gradient in a range from 3 to 10. Proteins were visualized in SDS-PAGE polyacrylamide gels by high sensitivity silver staining. ${ }^{41}$

2-DE gels were evaluated visually by a trained observer on a light box (Biotec-Fischer, Reiskirchen, Germany). Spot changes were considered with respect to presence/absence, quantitative variation and altered mobility. Mobility variants are spots that 'move' to a different position in the 2-DE gel indicating a shift of isoelectric point and/or molecular weight. Protein spots found to be reproducibly altered in protein patterns of hyperoxia-treated mice when compared to those of control animals were further evaluated with Proteomeweaver ${ }^{\mathrm{TM}}$ imaging software version 2.1 (Definiens, Munich, Germany). Following automatic spot detection and gel normalization, spot matching between all gels was viewed and edited where appropriate. Through automatic normalization, spot intensities are adjusted in such a way that they become comparable between different gels. The relative intensity of individual spots in 2-DE gels of hyperoxiatreated and control mice was quantified using a gray-scale and the difference between pairs determined. We calculated the median difference in relative spot intensities of matched spots. Protein alterations confirmed in at least four sample pairs were scored as significant.

\section{Protein identification}

For protein identification by MS, $40 \mu \mathrm{l}(\sim 20 \mu \mathrm{g} / \mu \mathrm{l})$ protein extract was separated on $1.5 \mathrm{~mm}$ diameter IEF and $1.0 \mathrm{~mm}$ SDS-PAGE gels and stained with an MS-compatible silver staining protocol. ${ }^{42}$ Protein spots of interest were excised from 2-DE gels and subjected to in-gel trypsin digestion without reduction or alkylation. ${ }^{42}$ Tryptic fragments were analyzed by matrix-assisted laser desorption ionization MS (MALDI-MS) or electrospray-ionization MS (ESI-MS). Mass spectra were analyzed using Mascot software 2.0 with automatic searches in SWISS-PROT and $\mathrm{NCBI}$ nonredundant databases. Search parameters allowed for one miscleavage and for oxidation of methionine and propionamidation of cysteine. Criteria for positive identification of proteins with MS were set according to the scoring algorithm delineated in Mascot (www.matrix science.com).

\section{Semiquantitative RT-PCR}

Retrosplenial cortices were rapidly collected, pooled, snap-frozen in liquid nitrogen and stored at $-80^{\circ} \mathrm{C}$. Total cellular RNA was isolated by acidic phenol/chloroform extraction. Prior to reverse transcription, possible DNA contamination was checked by running RNA samples on a $1 \%$ agarose gel subsequently developed with ethidium bromide. In all, $500 \mathrm{ng}$ of RNA was reverse transcribed at $42^{\circ} \mathrm{C}(1 \mathrm{~h})$ with $200 \mathrm{U}$ of Moloney murine leukemia virus reverse transcriptase and $2 \mu \mathrm{M}$ oligo $\mathrm{d}(\mathrm{T})_{15}$-primer (Promega, Madison, WI, USA) in $25 \mu \mathrm{l}$ of reaction mixture. Primer sequences designed for PCR amplification of CRMP2 and CRMP4 segments were $5^{\prime}$ ACCAACTGCCCTCTGTATGTC-3' (forward) and $5^{\prime}$-CCAGTTCTTGCTC CAGTAATG-3' (reverse), 5'-GCTGCTGTGACTATGCTTTGC-3' (forward) and 5'-CTTCCTGGCTTGTGAGATGAG-3' (reverse), respectively. PCR cycling conditions are available from the authors on request. Amplified cDNA was subjected to $5 \%$ polyacrylamide gel electrophoresis, subsequent silver staining and densitometric analysis with an image analysis program (BioDocAnalyze, Whatman Biometra, Göttingen, Germany).

\section{Western blots}

For Western blotting, brains were homogenized (900 r.p.m., $\left.4^{\circ} \mathrm{C}\right)$ in lysis buffer $(\mathrm{pH} 7.6,50 \mathrm{mM}$ Tris, $166 \mathrm{mM} \mathrm{KCl}, 5 \mathrm{mM}$ ethylene diamine tetraacetic acid, $1 \%$ Triton $\mathrm{X}-100)$ containing a mixture of protease and phosphatase inhibitors ( $1 \mathrm{mM}$ phenylmethylsulfonyl fluoride, $0.5 \mu \mathrm{g} / \mathrm{ml}$ leupeptin, $1 \mu \mathrm{g} / \mathrm{ml}$ pepstatin, $2 \mu \mathrm{g} / \mathrm{ml}$ aprotinin, $1 \mathrm{mM}$ sodium orthovanadate). The homogenate was centrifuged at $1050 \times g\left(4^{\circ} \mathrm{C}\right)$ for $10 \mathrm{~min}$, the microsomal fraction was subsequently centrifuged at $17000 \times g\left(4^{\circ} \mathrm{C}\right)$ for $20 \mathrm{~min}$ and the resulting supernatant was collected. Protein concentrations were determined using the bicinchoninic acid kit (Interchim, Montluçon, France) according to the protocol supplied by the manufacturer. Protein extracts $(30 \mu \mathrm{g})$ and a biotinylated Mw marker (Cell Signaling Technology, Beverly, MA, USA) were denaturated in Laemmli sample loading buffer (pH 6.8, 50\% glycerol, 2\% SDS, 5\% $\beta$-mercaptoethanol, $62.5 \mathrm{mM}$ Tris, $0.1 \mathrm{mg} / \mathrm{ml}$ bromophenol blue) at $95^{\circ} \mathrm{C}$, separated by $10.5 \%$ SDS-PAGE and electrotransferred in transfer buffer ( $80 \mathrm{mM}$ Tris, $39 \mathrm{mM}$ glycine, $20 \%$ methanol) to a nitrocellulose membrane $(0.2 \mu \mathrm{m}$; Protran, Schleicher \& Schuell, Dassel, Germany).

Blotting membranes were rinsed with Tween-containing Tris-buffered saline (TBST; $10 \mathrm{mM}$ Tris, $150 \mathrm{mM} \mathrm{NaCl}, 0.1 \%$ Tween, $\mathrm{pH} \mathrm{7.4)} \mathrm{and}$ treated with blocking solution ( $5 \%$ non-fat dry milk in TBST) for $2 \mathrm{~h}$ at room temperature to prevent nonspecific antibody binding. Equal loading and transfer of proteins was confirmed by staining membranes with Ponceau $S$ solution (Fluka, Buchs, Switzerland). Membranes were incubated overnight at $4^{\circ} \mathrm{C}$ with rabbit anti-TUC-4 (=CRMP-4) polyclonal antibody (1:5000; Chemicon, Temecula, CA, USA), mouse anti-nestin monoclonal antibody (1:250; Chemicon), goat anti-DCX polyclonal antibody (1:500; Santa Cruz Biotechnology) or rabbit anti-cleaved caspase-3 polyclonal antibody (1:1000; Cell Signaling technology), respectively. Thereafter, they were incubated with horseradish peroxidase-labeled secondary antibody (anti-rabbit 1:2000, Amersham Pharmacia Biosciences, Buckinghamshire, UK; anti-mouse 1:2000, Dako, Glostrup, Denmark; anti-goat, $1: 2000$, Vector Laboratories) at room temperature. The immunoreactive protein was detected by the enhanced chemiluminescence system (ECL, Amersham Pharmacia Biosciences) and serial exposures were made on autoradiographic film (Hyperfilm ECL, Amersham Pharmacia 
Biosciences). Densitometric analysis of the blots was performed with the image analysis program BioDocAnalyze (Biometra). Results of densitometric measurements of Western blots were statistically analyzed by means of Student's $t$-test to reveal differences between groups.

\section{Protein carbonyl assay}

Brain proteins were extracted as described above, and $20 \mu \mathrm{g}$ of protein was assayed for protein carbonyls using OxyBlot ${ }^{\mathrm{TM}}$ Protein Oxidation Detection Kit (Chemicon, Planegg-Munich, Germany) according to the manufacturer's instructions. Briefly, proteins were diluted with SDS for a final concentration of $6 \%$ SDS and incubated with an equal volume of 2,4dinitrophenylhydrazine (DNP) for $15 \mathrm{~min}$. After the reaction, samples were neutralized, electrophoresed on NuPage gels (Invitrogen, Karlsruhe, Germany), transferred to nitrocellulose membrane (Protran) and Westernblotted. Oxidatively damaged proteins were identified using an antibody specific to the dinitrophenylhydrazone-derivatized residues. Blots were stripped and subsequently reprobed for actin (AC-15, Abcam, Cambridge, MA, USA) to confirm equivalent protein loading. SDS-PAGE gels were stained with Coomassie blue staining as previously described. ${ }^{40,41}$ Protein carbonyls were also identified following 2-DE through a modified protocol. Prior to derivatization, brain proteins were separated in $15 \mathrm{~cm}$ IEF gels according to their isoelectric point using the mobile ampholyte technique described above. Following IEF, gels were incubated in DNP, neutralized after $15 \mathrm{~min}$ and then prepared for $\mathrm{Mw}$ separation in SDS-PAGE polyacrylamide gels. Oxidatively damaged proteins were identified as described above.

\section{Acknowledgements}

We acknowledge the assistance by Janine Stuwe, Silke Becker, Jessica Fassbaender, Mario Wolters and Gisela Stoltenburg-Didinger. This work was supported by the German ministry for education and research (BMBF), project no. 01ZZ 0101, the German national genome research network (NGFN) and by Sanitaetsrat Dr. Emil Alexander Huebner und Gemahlin-Stiftung.

\section{References}

1. Taylor HG, Minich NM, Klein N and Hack M (2004) Longitudinal outcomes of very low birth weight: neuropsychological findings. J. Int. Neuropsychol. Soc. 10: $149-163$

2. Wood NS, Marlow N, Costeloe K, Gibson AT and Wilkinson AR (2000) Neurologic and developmental disability after extremely preterm birth. EPICure Study Group. N. Engl. J. Med. 343: 378-384

3. Ajayi-Obe M, Saeed N, Cowan FM, Rutherford MA and Edwards AD (2000) Reduced development of cerebral cortex in extremely preterm infants. Lancet 356: 1162-1163

4. Abernethy LJ, Palaniappan M and Cooke RW (2002) Quantitative magnetic resonance imaging of the brain in survivors of very low birth weight. Arch. Dis. Child. 87: 279-283

5. Murphy DJ, Sellers S, MacKenzie IZ, Yudkin PL and Johnson AM (1995) Case-control study of antenatal and intrapartum risk factors for cerebral palsy in very preterm singleton babies. Lancet 346: 1449-1454

6. Ikonomidou C, Bosch F, Miksa M, Bittigau P, Vockler J, Dikranian K, Tenkova TI, Stefovska V, Turski L and Olney JW (1999) Blockade of NMDA receptors and apoptotic neurodegeneration in the developing brain. Science 283: 70-74

7. Ikonomidou C, Bittigau P, Ishimaru MJ, Wozniak DF, Koch C, Genz K, Price MT, Stefovska V, Horster F, Tenkova T, Dikranian K and Olney JW (2000)
Ethanol-induced apoptotic neurodegeneration and fetal alcohol syndrome. Science 287: 1056-1060

8. Hoehn T, Felderhoff-Mueser U, Maschewski K, Stadelmann C, Sifringer M, Bittigau P, Koehne P, Hoppenz M, Obladen M and Buhrer C (2003) Hyperoxia causes inducible nitric oxide synthase-mediated cellular damage to the immature rat brain. Pediatr. Res. 54: 179-184

9. Felderhoff-Mueser U, Bittigau $P$, Sifringer M, Jarosz B, Korobowicz E, Mahler L, Piening T, Moysich A, Grune T, Thor F, Heumann R, Buhrer $C$ and Ikonomidou C (2004) Oxygen causes cell death in the developing brain. Neurobiol. Dis. 17: 273-282

10. Felderhoff-Mueser U, Sifringer M, Polley O, Dzietko M, Leineweber B, Mahler L, Baier M, Bittigau P, Obladen M, Ikonomidou C and Buhrer C (2005) Caspase-1-processed interleukins in hyperoxia-induced cell death in the developing brain. Ann. Neurol. 57: 50-59

11. Lenn NJ (1987) Neuroplasticity and the developing brain: implications for therapy. Pediatr. Neurosci. 13: 176-183

12. Buonocore G, Perrone $S$ and Bracci $R$ (2001) Free radicals and brain damage in the newborn. Biol. Neonate 79: 180-186

13. Dobbing J (1974) The later growth of the brain and its vulnerability. Pediatrics 53: $2-6$

14. Lagercrantz $\mathrm{H}$ and Ringstedt $\mathrm{T}$ (2001) Organization of the neuronal circuits in the central nervous system during development. Acta. Paediatr. 90: 707-715

15. Gauss C, Kalkum M, Lowe M, Lehrach H and Klose J (1999) Analysis of the mouse proteome (I) brain proteins: separation by two-dimensional electrophoresis and identification by mass spectrometry and genetic variation. Electrophoresis 20: $575-600$

16. Onodera K, Omoi NO, Fukui K, Hayasaka T, Shinkai T, Suzuki S, Abe K and Urano S (2003) Oxidative damage of rat cerebral cortex and hippocampus, and changes in antioxidative defense systems caused by hyperoxia. Free Radic. Res. 37: 367-372

17. Goldman EH, Chen L and Fu H (2004) Activation of apoptosis signal-regulating kinase 1 by reactive oxygen species through dephosphorylation at serine 967 and 14-3-3 dissociation. J. Biol. Chem. 279: 10442-10449

18. Fu H, Subramanian RR and Masters SC (2000) 14-3-3 proteins: structure, function, and regulation. Annu. Rev. Pharmacol. Toxicol. 40: 617-647

19. Arias C, Becerra-Garcia F, Arrieta I and Tapia R (1998) The protein phosphatase inhibitor okadaic acid induces heat shock protein expression and neurodegeneration in rat hippocampus in vivo. Exp. Neurol. 153: 242-254

20. Launey T, Endo S, Sakai R, Harano J and Ito M (2004) Protein phosphatase 2A inhibition induces cerebellar long-term depression and declustering of synaptic AMPA receptor. Proc. Natl. Acad. Sci USA 101: 676-681

21. Liu H, Wang Y, Zhang Y, Song Q, Di C, Chen G, Tang J and Ma D (1999) TFAR19, a novel apoptosis-related gene cloned from human leukemia cell line TF-1, could enhance apoptosis of some tumor cells induced by growth factor withdrawal. Biochem. Biophys. Res. Commun. 254: 203-210

22. Rui M, Chen Y, Zhang Y and Ma D (2002) Transfer of anti-TFAR19 monoclonal antibody into HeLa cells by in situ electroporation can inhibit the apoptosis. Life Sci. 71: 1771-1778

23. Kitsberg D, Formstecher E, Fauquet M, Kubes M, Cordier J, Canton B, Pan G, Rolli M, Glowinski J and Chneiweiss H (1999) Knock-out of the neural death effector domain protein PEA-15 demonstrates that its expression protects astrocytes from TNF-alpha-induced apoptosis. J. Neurosci. 19: 8244-8251

24. Kamsler A and Segal M (2003) Hydrogen peroxide modulation of synaptic plasticity. J. Neurosci. 23: 269-276

25. Mattson MP and Liu D (2002) Energetics and oxidative stress in synaptic plasticity and neurodegenerative disorders. Neuromolecular Med. 2: 215-231

26. Chin LS, Li L, Ferreira A, Kosik KS and Greengard P (1995) Impairment of axonal development and of synaptogenesis in hippocampal neurons of synapsin I-deficient mice. Proc. Natl. Acad. Sci. USA 92: 9230-9234

27. Nonet ML, Grundahl K, Meyer BJ and Rand JB (1993) Synaptic function is impaired but not eliminated in $C$. elegans mutants lacking synaptotagmin. Cell 73: 1291-1305

28. Gundelfinger ED, Kessels MM and Qualmann B (2003) Temporal and spatial coordination of exocytosis and endocytosis. Nat. Rev. Mol. Cell. Biol. 4: 127-139

29. Hua JY and Smith SJ (2004) Neural activity and the dynamics of central nervous system development. Nat. Neurosci. 7: 327-332

30. Francis F, Koulakoff A, Boucher D, Chafey P, Schaar B, Vinet MC, Friocourt G, McDonnell N, Reiner O, Kahn A, McConnell SK, Berwald-Netter Y, Denoulet P 
and Chelly J (1999) Doublecortin is a developmentally regulated, microtubuleassociated protein expressed in migrating and differentiating neurons. Neuron 23: 247-256

31. Tolner EA, van Vliet EA, Holtmaat AJ, Aronica E, Witter MP, da Silva FH and Gorter JA (2003) GAP-43 mRNA and protein expression in the hippocampal and parahippocampal region during the course of epileptogenesis in rats. Eur. J. Neurosci. 17: 2369-2380

32. Kaibuchi K, Kuroda S and Amano M (1999) Regulation of the cytoskeleton and cell adhesion by the Rho family GTPases in mammalian cells. Annu. Rev. Biochem. 68: 459-486

33. Arimura N, Menager C, Fukata $Y$ and Kaibuchi K (2004) Role of CRMP-2 in neuronal polarity. J. Neurobiol. 58: 34-47

34. Arimura N, Inagaki N, Chihara K, Menager C, Nakamura N, Amano M, Iwamatsu A, Goshima Y and Kaibuchi K (2000) Phosphorylation of collapsin response mediator protein-2 by Rho-kinase. Evidence for two separate signaling pathways for growth cone collapse. J. Biol. Chem. 275: 2397323980

35. Quinn CC, Gray GE and Hockfield S (1999) A family of proteins implicated in axon guidance and outgrowth. J. Neurobiol. 41: 158-164

36. Suzuki Y, Nakagomi S, Namikawa K, Kiryu-Seo S, Inagaki N, Kaibuchi K, Aizawa H, Kikuchi K and Kiyama H (2003) Collapsin response mediator protein-2 accelerates axon regeneration of nerve-injured motor neurons of rat. J. Neurochem. 86: 1042-1050

37. Inagaki N, Chihara K, Arimura N, Menager C, Kawano Y, Matsuo N, Nishimura T, Amano M and Kaibuchi K (2001) CRMP-2 induces axons in cultured hippocampal neurons. Nat. Neurosci. 4: 781-782

38. Malorni W, losi F, Mirabelli F and Bellomo G (1991) Cytoskeleton as a target in menadione-induced oxidative stress in cultured mammalian cells: alterations underlying surface bleb formation. Chem. Biol. Interact. 80: 217-236

39. Swann JW and Hablitz JJ (2000) Cellular abnormalities and synaptic plasticity in seizure disorders of the immature nervous system. Ment. Retard. Dev. Dis. 6: 258-267

40. Palacino JJ, Sagi D, Goldberg MS, Krauss S, Motz C, Wacker M, Klose J and Shen J (2004) Mitochondrial dysfunction and oxidative damage in Parkindeficient mice. J. Biol. Chem. 279: 18614-18622

41. Klose J, Nock C, Herrmann M, Stuhler K, Marcus K, Bluggel M, Krause E, Schalkwyk LC, Rastan S, Brown SD, Bussow K, Himmelbauer $\mathrm{H}$ and Lehrach H. (2002) Genetic analysis of the mouse brain proteome. Nat. Genet. 30: 385-393

42. Shevchenko A, Wilm M, Vorm O and Mann M (1996) Mass spectrometric sequencing of proteins silver-stained polyacrylamide gels. Anal. Chem. 68: 850-858 